\title{
'Killing the Tree by Cutting the Foliage Instead of Uprooting It?' Rethinking awareness campaigns as a response to trafficking in South-West Nigeria
}

\author{
Peter Olayiwola
}

\section{Abstract}

Child domestic work is one of the issues often connected with human trafficking in popular discourses. The idea of ignorant and unsuspecting parents and children being tricked into situations of trafficking for domestic labour is rife and has driven education and awareness campaigns as keys to addressing trafficking. This paper offers a critique of awareness creation as an anti-trafficking strategy. Based on an ethnographic study of child domestic work in South-West Nigeria and an analysis of secondary sources, this article reviews the ignorance assumption in trafficking discourses. It contends that the existing strategy of awareness creation, often framed to discourage migration and work, misrepresents young domestic workers and/or their parents and fails to address the issues that children and/or their parents are faced with. The paper concludes by arguing for the need to address the structural root causes of trafficking rather than simply raise awareness of individual migrants.

Keywords: human trafficking, child domestic work, anti-trafficking, awareness campaigns, Nigeria

Please cite this article as: P Olayiwola, "Killing the Tree by Cutting the Foliage Instead of Uprooting It?” Rethinking awareness campaigns as a response to trafficking in South-West Nigeria', Anti-Trafficking Review, issue 13, 2019, pp. 50-65, https://doi.org/10.14197/atr.201219134

This is an open-access article distributed under the terms of the Creative Commons Attribution License (CC-BY). Under the CC-BY license, the public is free to share, adapt, and make commercial use of the work. Users must always give proper attribution to the authors and the Anti-Trafficking Review. 


\section{Introduction}

Different organisations, activists and scholars working in the field of anti-trafficking have identified a number of factors as contributing to child domestic work $(\mathrm{CDW})^{1}$ and the related issues of child labour and child trafficking. One of these is ignorance-of parents, children and the wider society. The ignorance explanation is multi-dimensional, according to them. For example, it is believed that most parents, when sending their children into domestic service, are simply not aware of the consequences of their actions and in most cases, children also do not know what awaits them before leaving their parents' homes; ${ }^{2}$ or that the general public in some countries is simply uninformed, according to the UNESCO. ${ }^{3}$

Olubukola Adesina corroborates the UNESCO's view by claiming that many parents in Nigeria are ignorant of what constitutes trafficking in her study of 'modern day slavery in Nigeria'. ${ }^{4}$ With regards to child domestic workers, it is also claimed that even in cases of abuse and exploitation, most of them are ignorant of their rights and often do not know where to go to for support. ${ }^{5}$ The ignorance explanation is also usually linked to certain customs and traditions in Africa and other parts of the world. ${ }^{6}$

1 In this paper, I use the term 'child domestic work' loosely to refer to domestic tasks undertaken as an economic activity by under-18s in households of third parties, and the terms 'young domestic workers', 'adolescent domestic workers' and 'child domestic workers' interchangeably to refer to individuals engaged in such tasks. Although I recognise that anti-trafficking organisations try to distinguish between 'acceptable child domestic work' and 'exploitative child labour', I also recognise that such rigid distinction and binary classifications do not reflect the dynamics of work relations.

2 Save the Children, Abuse among Child Domestic Workers: A research study in West Bengal, Save the Children, Calcutta, 2006; O S Adesina, 'Modern Day Slavery: Poverty and child trafficking in Nigeria', African Identities, vol. 12, issue 2, 2014, pp. 165-179, https://doi.org/10.1080/14725843.2014.881278.

3 UNESCO, Human Traffcking in Nigeria: Root causes and recommendations, Policy Paper, Poverty Series no. 14, issue 2, Paris, 2006, p. 38.

4 Adesina, 2014.

5 See, for example: C Flores-Oebanda, R Pacis and J Alcantara, Reaching out Beyond Closed Doors: A primer on child domestic labor in the Philippines, Visayan Forum Foundation, Manila, 2004; S Chodhuary, M Islam and J Akter, Exploring the Causes and Process of Becoming Child Domestic Worker, Working Paper no. 35, Research and Evaluation Division (RED), BRAC, Dhaka, 2013.

6 See, for example: C Flores-Oebanda, R Pacis and J Alcantara, 2004; H van de Glind, 'Child Trafficking: A modern form of slavery' in Gary Craig (ed.), Child Slavery Now: A contemporary reader, Polity Press, Bristol, 2010, pp. 99-116; ILO-IPEC, Ending Child Labour in Domestic Work and Protecting Young Workers from Abusive Working Conditions, ILO, Geneva, 2013. 
Given the predominance of this supposed ignorance, campaigners against child trafficking and child labour, including child domestic work, often emphasise the need to raise public awareness — especially through campaigns and empowerment programmes for vulnerable children and parents—as a way of eradicating child trafficking, child labour and child domestic work. ${ }^{7}$ In Guinea, Mali and Senegal, for example, NGO services for domestic workers include literacy and vocational classes and providing sensitisation programmes in rural areas 'to alert domestics about the hazards of urban migration'. ${ }^{8}$ In spite of these initiatives, scholars note that 'the level of awareness of the issue (of trafficking in general) is quite low in practically all spheres'.?

Against this backdrop, in this paper, I use agnotology (the study of ignorance) to examine whether such claims as above, that the awareness of the public about 'human trafficking' is generally low, are indeed correct and whether more awareness of trafficking will lead to fewer instances of it. By investigating how awareness campaigns are perceived and received by child domestic workers and/or their parents, I argue that the ignorance assumption misrepresents the situations of young domestic workers and/or their parents, and fails to address the structural root causes of trafficking, including poverty and inequalities that influence their decisions.

Robert Proctor's example of the tobacco industry's practices to hide tobacco hazards from the public shows how powerful institutions, in their bid to promote their interests, could be actively engaged in the process of 'manufacturing ignorance'. ${ }^{10}$ Proctor argued that beyond being a 'native state' or a 'lost realm', ignorance could be 'a deliberately engineered and strategic ploy'. ${ }^{11}$ In this sense, ignorance is significant in creating uncertainty; it makes one's actions excusable and also manufactures the ignorance of others by diverting attention and ignoring alternative explanations. ${ }^{12}$ Thus, ignorance as "strategic unknowns" remains a

7 C Flores-Oebanda, R Pacis and J Alcantara, 2004, p. 16; B Moens et al., Study on the Practice of Trafficking in Persons in Senegal, Development Alternatives, Bethesda, 2004; Human Rights Watch (HRW), 'Bottom of the Ladder: Exploitation and abuse of girl domestic workers in Guinea', vol. 19, issue 8, New York, 2007.

8 B Moens et al., p. 52; HRW, 2007.

9 B Moens et al., p. 58.

10 R Proctor, 'Agnotology: A missing term to describe the cultural production of ignorance (and its study)' in R Proctor and L Schiebinger (eds.), Agnotology: The making and unmaking of ignorance, Stanford University Press, Stanford, 2008, pp. 1-33, pp. 13-14.

11 Ibid., p. 3.

12 M Smithson, 'Social Theories of Ignorance', in ibid., pp. 209-229, p. 223; T Slater, 'The Myth of "Broken Britain": Welfare reform and the production of ignorance', Antipode, vol. 46, issue 4, 2014, pp. 948-969, p. 961, https://doi.org/10.1111/ anti.12002. 
resource-perhaps the greatest resource-for those in a position of power and those subject to it'. ${ }^{13}$ Consequently, there is a need to '....understand how and why various forms of knowledge have "not come to be," or disappeared, or have been delayed or long neglected, for better or for worse, at various points of history... . ${ }^{14}$

The remainder of this article is divided as follows: the next section briefly discusses the methodology which underpinned the arguments presented here. Following that, I examine the nature of awareness campaigns in Nigeria before I move on to the responses of the intended beneficiaries to awareness creation. In the last section, I argue that by not addressing the underlying reasons behind CDW, awareness campaigns have contributed to creating doubts and uncertainties about the plights of child domestic workers and their parents. I conclude by presenting alternative ways of addressing CDW.

\section{Methodology}

This article draws on individual and group interviews with key actors working on CDW, including children in domestic service, their parents, employers, intermediaries, government and NGO officials, conducted in South-West Nigeria between December 2017 and May 2018. The choice of the south-western region was informed by the fact that major cities in southern states attract substantial numbers of migrants, and it is in this context that many children are believed to be 'trafficked' into the region ${ }^{15}$ for domestic work.

Initial participants were recruited through existing contacts in Lagos, Ibadan and Abeokuta, and snowballing was used to recruit others in these sites as well as in nearby villages. In addition, my familiarity with the geography and culture of the region was significant in the choice of the study location, as I speak the local language (Yoruba) and have personal and professional networks in these cities.

In all cases, I conducted the interviews in either the local languages (Yoruba or Pidgin English) or English. In total, I interviewed 49 current and eleven former CDWs; thirteen employers; eight government and NGO officials; and 21 other adults, including parents, intermediaries and key informants in the villages. I

13 L McGoey, 'Strategic Unknowns: Towards a sociology of ignorance', Economy and Society, vol. 41, no. 1, 2012, pp. 1-16, p. 1, https://doi.org/10.1080/03085147.201 1.637330 .

14 R Proctor and L Schiebinger (eds), Agnotology: The making and unmaking of ignorance, Stanford University Press, Stanford, 2008, p. vii.

15 Adesina, 2014. 
interviewed representatives of the Nigeria Immigration Service (NIS) and the National Agency for the Prohibition of Trafficking in Persons (NAPTIP) and of the following NGOs: Women Trafficking and Child Labour Eradication Foundation (WOTCLEF), Women Consortium of Nigeria (WOCON) and Justice Development and Peace Commission (JDPC)—well-known and established within the country and beyond. ${ }^{16}$ My efforts to interview officials of the International Labour Organization (ILO) and the United Nations International Children's Fund (UNICEF) in Nigeria were unsuccessful as they did not respond to my emails or answer calls to the designated mobile numbers. In addition to primary sources, I also relied on information from these organisations that are available in the public domain.

\section{CDW and Awareness Campaigns in Nigeria}

Perhaps unsurprisingly, the officials I interviewed echoed most of the claims in the literature even when they have little or no empirical justification. According to one NIS official in explaining the causes of trafficking and CDW:

... poverty might not be enough, someone that is poor but knowledgeable will know that taking care of the future of the child will be paramount in his/her mind - not to send such a child into servitude... ${ }^{17}$

Similarly, an official of NAPTIP noted:

... apart from poverty, there is need to re-orient our citizens.... Increase in awareness creation is key. Most parents don't know... If they know... they wouldn't fall prey to the antics of traffickers. ... That is what traffickers capitalise on - painting a rosy picture. ${ }^{18}$

And an NGO employee explained:

I think if you want to change this, it has to do with the parents... The parents have to understand... that not every story is true... ${ }^{19}$

16 Ibid.; V Nwogu, 'Anti-Trafficking Interventions in Nigeria and the Principal-Agent Aid Model', Anti-Trafficking Review, issue 3, 2014, pp. 41-63, https://doi.org/10.14197/ atr.20121433.

17 Interview, Government Official, Ibadan, 17 April 2018.

18 Interview, Government Official, Lagos, 19 March 2018.

19 Interview, NGO Official, Abuja, 23 March 2018. 
In all these narratives, the ignorance of the poor is correlated with their poverty. These narratives in many ways stigmatise the poor and reduce trafficking to an attitudinal problem. Thus, based on the widespread claim about people's ignorance, these organisations as well as their international partners, are involved in awareness creation as a preventive strategy in child trafficking and/or exploitation of child domestic workers, with the major goal being to 'sensitise and help' the people because 'people feel it [sending their children out to work in domestic service] is normal. ${ }^{20}$

NAPTIP is the main institution tasked with preventing and combating trafficking in Nigeria. The agency was established to enforce and harmonise the implementation of anti-trafficking legislation. Although the organisation is more notable for its work on trafficking for sexual exploitation of Nigerians abroad, it has also been involved in combating internal trafficking for labour and sexual exploitation. ${ }^{21}$ For example, NAPTIP undertakes sensitisation visits to communities where adolescent domestic workers migrate from, as well as rehabilitation schemes for 'victims'. ${ }^{22}$ Like NAPTIP, the three NGOs I visited implement advocacy and sensitisation programmes because they believe that people just do not know the implications of their actions and decisions. These programmes take place in different settings and may take different forms including occasional visits to some 'endemic communities', markets and motor parks, partnerships with NAPTIP and NIS in monitoring movements along Nigerian borders, or with community leaders, traditional rulers and religious organisations, among others, as exemplified by the following quotes:

We liaise with the traditional rulers... we also visit motor parks and market places for outreaches in those locations. ${ }^{23}$

... we started... to campaign against child trafficking and labour... We encouraged parents, we held household sensitisation talks, we had rallies, we had psychotherapy sessions for the children that were victims of these problems that we are talking about... And ... we set up a stakeholders' committee... It comprises the Nigerian Police, the Nigerian Immigration... ${ }^{24}$

20 Ibid.

${ }^{21}$ V Nwogu, 'Nigeria' in M Dottridge (ed.), Collateral Damage: The impact of anti-trafficking measures on human rights around the world, Global Alliance Against Traffic in Women, Bangkok, 2007; O O Oluwaniyi, 'Internal Child Trafficking in Nigeria: Transcending legal borders' in O Agbu (ed.), Children and Youth in the Labour Process in Africa, CODESRIA, Dakar, 2009, pp. 81-110.

22 Nwogu, 2007, p. 158

23 Interview, Government Official, Lagos, 19 March 2018.

24 Interview, NGO Official, Ibadan, 13 April 2018. 


\section{We entered radio jingles in a number of radio houses that have wide} coverage... we targeted some core programmes that they listen to... ${ }^{25}$

There are also popular home videos and documentaries in the country on the subject of human trafficking. ${ }^{26}$ Additionally, some of these organisations partner with youth organisations (like the National Youth Service Corps) and secondary schools to establish anti-trafficking clubs to prevent trafficking among young people. The idea is that classmates or peers can detect cases of trafficking more easily and in fact, they can go to places that we cannot go to because we are busy with office work. ${ }^{27}$

Awareness campaigns also involve partnerships between NGOs and security agencies. NGO and NAPTIP officials explained that their sensitisation programmes also target security personnel to alert them on the tactics of traffickers and how to handle them. ${ }^{28}$ Thus, awareness campaigns are also supplemented by an increase in surveillance and raids by security operatives. According to participants, NIS officials also visit markets and other public places to arrest adolescent domestic workers as a preventive measure. In addition, NIS officers admitted that with the free movement of people in the Economic Community of West African States (ECOWAS), it is difficult to monitor or control everyone. ${ }^{29}$

Awareness campaigns are often supported by 'empowerment programmes', i.e. income-generating activities proposed by some NGOs as alternatives to children working in domestic service. However, the fact that NGOs' funds are often limited means that there is usually little or no follow-up after the short-term lifecycle of such projects. One NGO representative told me of a project that they executed in Shaki town in 2002 to assist residents in generating income and stop them from sending their children out to work. Back then, it was lauded as a success model, ${ }^{30}$ but a few years later, the town is still believed to be a 'trafficking hub' ${ }^{31}$ A major reason for this is that while empowerment programmes may help locals start small businesses, they often fail to take into account the shocks and downturns they are susceptible to, or the (near) absence of basic infrastructures such as good roads and electricity that affect the marketing of their products. For farmers, for example, the problems of preservation and marketing of their crops, and the

\footnotetext{
25 Ibid.

26 Nwogu, 2014

27 Interview, NGO Official, Abuja, 23 March 2018.

28 Interview, Government Official, Lagos, 5 March 2018; Interview NGO Official, Abuja, 23 March 2018; Interview, NGO Official, Ibadan 13 April 2018.

29 Interview, Government Official, Ibadan, 5 March 2018.

30 Interview, NGO Official, Lagos, 5 March 2018.

31 Adesina, 2014.
} 
fluctuations in the prices of agricultural products make them vulnerable and susceptible to economic shocks-a major reason why some send their children into domestic service during the 'lean months or years'. ${ }^{32}$

Furthermore, in all cases, although NGO and government offices were laced with campaign posters and anti-trafficking materials, there were no such materials in public places in urban centres or anywhere in the rural areas. When I asked one official if they ever considered that their radio and TV programmes might not be reaching the people in the villages who may not have access to TV or even electricity, as my observation in the villages shows, she went on to explain that 'Seriously, government is the one saddled with such responsibilities [of providing basic amenities]...' on one hand, and on the other, that the local government or the community do 'employ the services of town criers in such cases. ${ }^{33}$

In this regard, campaigners do not seem to understand that their approach is lopsided at best- they are not addressing the supply side of 'trafficking' simply because most of their programmes are concentrated in urban centres as opposed to rural areas where many young domestic workers originate from. ${ }^{34}$ Most NGOs are based in urban centres, and their activities depend on funding and/or donors' agendas. ${ }^{35}$ As a result, they only visit rural areas when the opportunity presents itself. Beyond their limited geographical scope, the reduction of trafficking to an attitudinal problem as stated above means that much of the campaigning is underlined by the assumption that awareness would necessarily translate into a meaningful behavioural change. To assess how these messages are received by the intended beneficiaries, I sought the views of adolescents, parents and adults in some of the communities I visited. I asked them about their knowledge on the phenomenon of trafficking and what campaign strategies mean to them.

\section{Perception of 'Trafficking' by 'Victims' and the 'Ignorant'}

I found that, contrary to popular rhetoric, most of the parents and children had fairly good knowledge of what is commonly called 'trafficking' or 'modern slavery', even if they did not view their situations as such. For example, in one group discussion, several adolescent workers were asked whether they knew anything

32 Interview, Village Group 1, Ego village, 11 January 2018; Interviews, Owo village, 29 March 2018.

33 Interview, NGO Official, Ibadan, 13 April 2018.

34 ILO, Rural-Urban Migrants Employed in Domestic Work: Issues and challenges, Briefing note no. 5, Dar es Salaam, 2013.

35 Nwogu, 2014. 
about child trafficking and/or any government policy regarding working children. Below is an excerpt of their responses:

R2: I know of child abuse.

R3: I know of human trafficking. Trafficking is the transportation of human beings from one country to another by means of (hmmm) maybe through the desert or any means for hard labour, slavery, sexual exploitation.

Interviewer: Then, what else?

R1: Child rights... ${ }^{36}$

At another time, a former domestic worker responded:

Yes, I do hear about such, that it is against the law... ${ }^{37}$

And one parent said:

... they said that child labour or child domestic work is not good... ${ }^{38}$

In another instance at Ego village, while trying to explain trafficking and anti-trafficking campaigns to some adults, they all chorused:

Everyone listens to such on the radio. ${ }^{39}$

Employers and intermediaries also explained to me in different ways that they were aware of these topics and the associated policies and campaigns against them. In short, although there were some participants who said they had no knowledge of trafficking, the majority demonstrated basic understanding of what they believed trafficking is and what they thought the government and/or anti-trafficking campaigners were saying. But what do they do with such information? To them, it is just that-information that does not affect them in practical ways, and one that the campaigners themselves only pay lip service to, since campaigns do not address the reasons why children are engaged in domestic service. The next section discusses how the intended beneficiaries respond to campaigns and sensitisation programmes.

36 Interview, Adolescent Group 1, Ibadan, 11 May 2018.

37 Interview, Former child domestic worker 6, Ibadan, 26 February 2018.

38 Interview, Parent 6, Ibadan, 16 May 2018.

39 Interview, Village Group 1, Ego village, 11 January 2018. All names of individuals and villages (not the major cities) have been either changed or anonymised to protect the identity of informants. Details can be provided on request. 


\section{Responses to Awareness Campaigns}

Most respondents felt that awareness campaigns and anti-trafficking policies in general were not in their best interests, and as such they developed a range of alternatives that defy the message being passed across by campaigners. For example, for many rural dwellers, 'the city' is a land of opportunity, real or imagined, compared to the hardship and challenges of rural life. Moreover, for many rural children, their fantasy about the city is enhanced through interactions with, and observation of, returnee city dwellers, and they would readily jump at any invitation to live in the city. This is quite different from the idea of 'ignorant' and unsuspecting children and parents being tricked by traffickers as the dominant literature on CDW often explains: ${ }^{40}$ it is a choice often made in consideration of potential benefits and actual costs. Victoria, for example, recollected how she left for the city, where she now works in domestic service:

During our church camp meetings in the village, people from the
city do come and I do observe the way they relate with us, the way
they dress, the way they speak English, and all that... there are also
people that come to the village during Christmas that would bring
gifts for their parents, and go around greeting everybody. So, I have
always been impressed by that, and I do tell myself that I would be
doing that in the future, too. 41

When an opportunity came through a woman who would 'take care' of her and send her to school in the city while she would assist the woman at home, she did not hesitate. Even though it was her parents' and grandparents' decision, she said 'I liked it, too; I was looking forward to coming to the city'.

This challenges some of the dominant assumptions and stereotypes of anti-trafficking campaigns ${ }^{42}$ of a wily trafficker painting rosy pictures to deceive unsuspecting parents and/or children. Indeed, for all participants in my study, there was not a single case of a person being recruited as part of a group, or being promised 'big stuff' like cars or huge sums of money, as claimed by government and NGO-run campaigns. Rather, young people are in domestic service, in some cases, for basic sustenance and education, and in other cases, particularly for rural migrants or those from neighbouring West African countries, because it offers them opportunities for a better life.

40 See, for example: ILO, 2004; UNESCO, 2006.

41 Interview, Former child domestic worker 9, Ibadan, 2 March 2018.

42 See, for example: UNESCO, 2006; Adesina, 2014. 
In the latter case, and as the example of Victoria above shows, the status that migrants command in the village may serve as motivations for others to desire to migrate. ${ }^{43}$ This explains why children themselves (or their parents) may decide to look for an intermediary that will facilitate their migration for work. Thus, in almost all cases, migration decisions and recruitment were not through 'a closely-knitted and organised network', as it is popularly presented, but through informal channels such as extended family members, church members, Christian missionaries, neighbours, customers or clients, etc.

Also, like Victoria, other respondents explained that the prospects of being educated or raising capital for future businesses, which working in domestic service offered them, was more realistic than 'what the government is saying'. According to one young girl:

I was living with my mum before. But there was no money, no means of sending me to school. If I were staying with them, there is no way I would be going to school. ${ }^{44}$

A former domestic worker, who is now a trained tailor, said:

... I think that kind of job is just a temporary thing — a stepping stone to have something better to do in life... I cannot tell my younger one for example not to work for money now. He does not have anything to do now, and if he wants to go to school, there is no money for him to go to school... it is only a stepping-stone; a temporary work till he is able to learn a trade or something. ${ }^{45}$

Given the above, a recurring theme in my interactions with government and NGO officials was how some children (with or without the support of their parents) could be relentless in their attempts to migrate and/or work. The officials explained to me that even when potential young migrants had been repeatedly warned against migrating for work, and were subsequently arrested and reunited with their families, they almost always found ways to return to work. ${ }^{46}$

43 See, among others: S Castle and A Diarra, The International Migration of Young Malians: Tradition, necessity or rite of passage?, Research Report, London School of Hygiene and Tropical Medicine, London, 2003; A De Lang, 'Child Labour Migration and Trafficking in Rural Burkina Faso', International Migration, vol. 45, issue 2, 2007, pp. 147-167, https://doi.org/10.1111/j.1468-2435.2007.00407.x.

44 Interview, Child domestic worker 12, Ibadan, 26 February 2018.

45 Interview, Former (young) domestic worker 6, Ibadan, 26 February 2018.

46 Interview, Government Official, Ibadan, 5 March 2018; Interview, NGO Official, Ibadan 13 April 2018. 
However, for potential young migrants or domestic workers (and/or their parents), such actions are normal responses to messages of anti-trafficking campaigns that may be described as almost irrelevant to them and as removed from their lived realities. Individuals explore different channels, both legal and illegal, ${ }^{47}$ of migration and finding jobs when the official narrative does not address their needs. A study of anti-trafficking discourses and policies in Benin confirms this finding of (potential) young migrants seeking alternative means of migration when or where the legal channels are criminalised. ${ }^{48}$

Likewise, the idea that parents are often unaware of what their children do or the conditions they live under did not reflect the situation of my interviewees. Many domestic workers explained that in some cases when they had complained to their parents, they were encouraged to continue to 'endure' till they could get another job, or another means of sustenance or education-depending on their reasons for engaging in domestic service:

They always encourage me to endure till I complete my senior secondary school. ${ }^{49}$

According to one parent, speaking in relation to her two children in domestic service:

Sometimes, they may not be properly fed; they may be physically assaulted at work, and in some cases, they may not give them what they need in school. So, it is not as if all is perfect where they are, but they know that things are even worse at home in terms of basic provisions, so they'd rather endure whatever ill-treatment they face there, and they don't even tell me some of these things. ${ }^{50}$

These accounts show that the decisions to keep children in supposedly negative environments or to withdraw them are not taken lightly or presumptuously by the parents, but in considerations of the (immediate and future welfare of the child. ${ }^{51}$

47 These, according to respondents may include migrating through illegal routes, bribing officials at the borders, or bribing officials during raids. These often lead to additional costs that could potentially contribute to the exploitation of child domestic workers.

48 N Howard, 'Accountable to Whom? Accountable for what? Understanding anti-child trafficking discourse and policy in southern Benin', Anti-Trafficking Review, issue 1, 2012, pp. 43-59, https://doi.org/10.14197/atr.201213.

49 Interview, Adolescent domestic worker 25, Ibadan, 28 February 2018.

50 Interview, Parent 2, Ibadan, 28 January 2018.

51 I Hashim, and D Thorsen, Child Migration in Africa, Zed Books, London and New York, 2011. 
Similar to the above, it was made clear to me that when cases of extreme exploitation, such as non-payment of wages, are discovered, people do not report them to government agencies for fear of being misunderstood and/or prosecuted themselves, or even their children being deprived of the means of livelihood. An elderly woman in one of the villages explained:

You know with the government's stance that children should not be in domestic service again... they are saying children should not be lured into slavery now. So, you cannot go to report such to the law enforcement agents; such matters are usually resolved among the parties involved. ${ }^{52}$

While this means that children and parents have ways of escaping exploitation, it also means that elements of exploitation by some intermediaries cannot be checked, as they are not reported. As other studies have shown, legislation or specific interventions against working children in general can actually have negative consequences on the children and their families. ${ }^{53}$

Overall, when I presented some of the challenges that rural dwellers and children in domestic service (or their parents) raised with me to NGO and government officials, both were evasive in their responses. For example, as much as they agreed that poverty is a major contributing factor, when I asked NGO officials about poverty, I got responses like the following:

No doubt government has failed Nigerians as far as addressing poverty is concerned, but... ${ }^{54}$

Or when I asked a government official, I was told:

That (poverty question) is not a matter for Immigration! ${ }^{55}$

The above shows the politics of awareness creation-one that hides (or seeks to hide) the realities and constraints faced by the poorest or most vulnerable individuals under the guise of their ignorance, as I discuss in the next section.

52 Interview, Village Group 1, Ego village, 11 January 2018.

53 See, among others: M Jacquemin, 'Can the Language of Rights Get Hold of the Complex Realities of Child Domestic Work? The case of young domestic workers in Abidjan', Childhood, vol. 13, issue 3, 2006, pp. 389-406, https://doi. org/10.1177/0907568206066358.

54 Interview, NGO Official, Abuja, 23 March 2018.

55 Interview, Government Official, Ibadan, 17 April 2018. The official here meant that the issue of poverty is beyond the purview of his agency (the NIS). 


\section{Discussion and Conclusion}

Although there has been a great deal of media attention and awareness creation, this has not resulted in enhanced knowledge of, or effective policies to tackle trafficking and child domestic work; rather it has resulted in the production of certain kinds of ignorance. ${ }^{56}$ This is because campaigns are often about 'individualizing explanations and exceptionalizing representations of trafficking'57 while ignoring macro-level realities that confront parents and children. Thus, questions should go beyond asking what parents and/or their children do or do not know about trafficking to how and why they do not know what they do not know-do they not want or prefer not to know? To put it differently, is it the outcome of the lack of information or of how the information is presented? Arguably, it is the latter.

For poor or the most vulnerable people, the problem is not just that they are faced with poverty, but that the circumstances contributing to their poverty are not addressed. For these individuals, it is not a matter of 'not knowing', as antitrafficking campaigners claim, but of how the alternatives available to them are depicted. To them, awareness campaigns without any formal support system do nothing to help them alleviate their respective situations, and they would rather stick with the means of survival — a form of social protection - that CDW serves them. On the other hand, for those who are in domestic service for reasons other than absolute deprivation, it simply makes no sense to tell them not to work when it represents the best means to fulfil their life projects.

As one agnotological critique ${ }^{58}$ of the UK Centre for Social Justice's work on welfare and poverty shows, presenting trafficking as a problem of ignorance means deflecting attention away from the reality of structures and processes within which exploitation occurs. Thus, the structural causes of trafficking are strategically ignored in favour of a single problem, of ignorance, to be tackled by 'awareness creation'. By ignoring such structural constraints, awareness creation creates doubts and uncertainties for the general public about the difficulties faced by children in domestic service and/or their parents, as some of the responses above show. As the head of the anti-trafficking unit of a government agency in one of the sites explained when asked about the challenges with anti-trafficking efforts in general,

56 J Mendel and K Sharapov, 'Human Trafficking and Online Networks: Policy, analysis, and ignorance', Antipode, vol. 48, no. 3, 2016, pp. 665-684, https://doi.org/10.1111/ anti.12213.

57 K Sharapov and J Mendel, 'Trafficking in Human Beings: Made and cut to measure? Anti-trafficking docufictions and the production of anti-trafficking truths', Cultural Sociology, vol. 12, no. 4, 2018, pp. 540-560, p. 544, https://doi.org/10.1177/ 1749975518788657.

58 Slater, 2014. 
the issue relates to wider social structures where people do not have access to quality education, decent employment and social protections. To him, campaigns and the actions of the government amount to 'killing the tree by cutting the foliage instead of uprooting it. ${ }^{59}$

Further, as Kempadoo has argued, ${ }^{60}$ anti-trafficking campaigns do not learn from and respect the views of those classified as 'victims' - in this case, children in domestic service and/or their parents-about their lives and work situations. Instead, their views are presented as uninformed, and they are depicted as incapable of knowing, at least not without help from 'the experts'.

What the above has shown is that the ignorance assumption that drives awareness campaigns is greatly flawed because it distorts the realities of young domestic workers and/or their parents and misrepresents their motivations for entering into domestic service. While this article acknowledges that there are exploitative practices in CDW, it also argues that it presents a viable alternative for many households to navigate their disadvantaged positions in a structure of inequality and a society without any formal support system or social protection. Although organisations like the ILO have identified the significance of social protection in addressing poverty, economic vulnerabilities, business shocks, etc. as factors driving children to work, ${ }^{61}$ these do not become the subjects of campaigns. This is why such campaigns do not seem to have any impact on the poorest households and/ or potential young migrants or labourers. To them, NGOs and government agencies should not be 'creating awareness' when they themselves do not seem to be aware of the grinding poverty of young migrants and their families or the limited opportunities available to them.

The lingering question for anti-trafficking campaigners is this: if poverty is identified as a root cause or contributing factor to children being sent by their parents or deciding for themselves to work in domestic work, which makes them vulnerable for exploitation and child trafficking, how do awareness campaigns address the issue of poverty? As has been observed, ${ }^{62}$ although information about trafficking is useful, Nigeria as a country is already saturated with it; the fact that information does nothing to address the reasons for migration makes it even less effective as a means of preventing trafficking - for domestic work or otherwise.

59 Interview, Government Official, Ibadan, 17 April 2018.

60 K Kempadoo, 'The Modern-Day White (Wo)Man's Burden: Trends in anti-trafficking and anti-slavery campaigns', Journal of Human Trafficking, vol. 1, no. 1, 2015, pp. 8-20, https://doi.org/10.1080/23322705.2015.1006120.

$61 \quad$ ILO, 'World Report', 2013.

62 Nwogu, 2014. 
Peter Olayiwola is a doctoral student at the School of Sociology and Social Policy, University of Nottingham. His research interests include migration, human trafficking, inequalities and poverty. He holds a BSc in Sociology \& Anthropology (First Class) from Obafemi Awolowo University, Nigeria, and was previously a Commonwealth Shared Scholar at the School of Oriental and African Studies, University of London, where he completed his MSc in Development Studies with Distinction. Email: peter.olayiwola1@nottingham.ac.uk 